or newer than the Boulder-clay east of Grantham. Mr. Deeley regards it as older because the material is similar to that of his older Pleistocene sands; he may be right, but neither I nor my colleagues bave found any deposits elsewhere in Lincolnshire which could be regarded as distinct from, and older than, the great chalky Boulderclay.

The only locality where any great mass of Glacial gravel exists is around Benniworth, near Donnington, and this will be described in the forthcoming memoir on Sheet 83 of the Geological Survey Map. There, if anywhere, will Mr. Deeley find the analogue of his Older Pleistocene; but I very much doubt whether clays containing Pennine detritus ever extended so far to the east. If any Older Pleistocene deposits existed in East Lincolnshire, I should expect them to be rather of the Cromer than of the Pennine type.

With regard to the marine origin of the Newer Glacial clays, I would call attention to the remarkable deposits near Kirmington in North Lincolnshire, where laminated loams and sands containing perfect shells are associated with Boulder-clay of the Hessle type in such a way as to lead to the conclusion that they all belong to one group. These beds were carefully studied by Mr. C. Reid, and it is to be hoped that a description of them may soon be published.

The most surprising statement in Mr. Deeley's article is that many geologists regard the glaciated surfaces beneath the Drift of Lancashire as caused by large icebergs grating along the bottom of a sea about 1200 feet deep! He must have strangely misunderstood the views of those who believe the striæ to have been caused by sea-ice, and surely a little consideration will enable him to see that every single striated surface might have been glaciated in shallow water during the progress of a gradual submergence. I certainly never heard of any one who supposed that no such action occurred till the water was 1200 feet deep.

Mr. Deeley has done good work in the Midlands ; let me recommend him to take his note-book into Lincolnshire, and when he publishes his observations, to keep his facts rigidly apart from his theories.
ShIrLex, Sovthampton.
A. J. Jukes-Browne.

\title{
DISCOVERY OF LOWER CARBONIFEROUS BEDS IN UPPER EGYPT.
}

Srr,-The discovery of Lower Carboniferous beds in the wild region between the Nile and the Gulf of Suez adds a new feature of interest to the Geology of Egypt. The announcement is contained in a memoir by Dr. Schweinfurth, of Cairo, of which he has been kind enough to forward me a copy containing the result of an exploration by himself and M. Walther, of Jena, into the valley of the Arabah, and communicated to the Egyptian Institute. ${ }^{1}$ At first I was somewhat startled by the title and the early pages of the memoir, as the members of the Expedition of the Palestine Exploration Society (1883-4) bad failed to notice any Carboniferous beds in the Wâdi Arabah, at the head of the Gulf of Akabah, until we lighted upon

\footnotetext{
1 "Sur une récente Exploration Géologique de l'Ouadi Arabah," Le Caire, 1888.
} 
them at Lebrusch, on the flanks of the Moabite hills above the shore of the Dead Sea. I supposed, therefore, that Dr. Schweinfurth had found what we had failed to notice. But, on reading further, the matter was set at rest. It is somewhat unfortunate, and tending to confusion, that there are two Arabah valleys, one in the eastern part of upper Egypt, opening out on the Gulf of Suez, and the other connecting the Gulf of Akabah with the Dead Sea and Jordan Valley. The former is that referred to by the African explorer, and is of special importance as helping to connect the geology of the Upper Nile Valley with that of Arabia Petræa. Dr. Schweinfurth recognizes the identity of the beds he describes with those of the Wadi $\mathrm{Nasb}$ in the Sinaitic Peninsula, where limestone containing fossils of Carboniferous Limestone age, first discovered by Mr. Bauerman, are interposed between crystalline rocks and sandstones and other strata of Cretaceous age. These beds were afterwards examined by Col. Sir Charles Wilson and by the Members of the Expedition of 1883-84, and the fossils brought home by them were determined by Prof. Sollas. ${ }^{1}$ Of this identification of the beds of the Wadis Nasb and Arabah there can be no question, as the genera of the fossils are in most cases identical, and the species characteristically Carboniferous.

The following is a section of the beds in the escarpment of the southern flank of the plateau of north Galala, descending to the bottom of the Wadi Arabah, in Upper Egypt, as given by Dr. Schweinfurth :-

Summit of Escarpment; $1400 \mathrm{~m}$. above the sea.

$300 \mathrm{~m}$.-Terraines Tertiaires du Parisien.

$200 \mathrm{~m}$.- Terraines Tertiaires I,ondinien (?).

$200 \mathrm{~m}$.-Banks of débris covering Cretaceous-beds of Stages Up. and Lr. Senonien.

$50 \mathrm{~m}$.-Argillaceous and Marly ochreous Limestone and sandy beds with Ammonites. Senonien inferieur.

$250 \mathrm{~m}$.-Escarpment of red Nubian Sandstone. (Terrains Crétacés d'incertains étages).

(Geat Geological hiatus.)

2 m.-Dark Sandstones with silicified wood (Araucarioxylon). Lower Carboniferous.

$60 \mathrm{~m}$.- Solid and soft Sandstones and Marls, with fragments of Crinoids, and Spirigera.

I m.-Bed of hard blue Limestone-with Crinoids, Productus, Spirifer, etc.(Carboniferous Limestone).

$40 \mathrm{~m}$. - Marls and Sandstone partly fossiliferous.

Lower Casboniferous.

(Details of beds below this not giren.)

Geological Survey Office, Dublin, 23 May, 1888.

E. H.

THE ATMOSPEERE OF THE COAL PERIOD.

Sir,-From the silence of your reviewer, I presume that he is unable to verify the assertion so often made that experiments had proved the improbability of plants living in an atmosphere containing an excess of carbonic acid. As I before remarked, very few definite experiments had been made besides the one $I$ have quoted in my work. I might, however, have referred to those made by

1 "Physical Geology of Arabia Petræa and Palestine," Mem. Palestine Exploration Fund, p. 48. 